\title{
Synthesis, Characterization and Biological Studies of Porphyrinyloxovanadium(IV)benzimidazole Complexes
}

\author{
GAURI D. BAJJU*, VED KUMAR, ASHU and GITA DEVI \\ Department of Chemistry, University of Jammu-180 006, Jammu \& Kashmir, India \\ gauribajju@gmail.com
}

Received 3 September 2014 / Accepted 25 September 2014

\begin{abstract}
The six-coordinate oxovanadium(IV) complexes [VO(RTPP)(L)] (where R=H, methyl, methoxy and chloro groups and $\mathrm{L}=$ methyl and ethyl substituted benzimidazoles) were prepared by reacting the ligands; 2-methylbenzimidazole and 2-ethylbenzimidazole with various VO(RTPP). The complexes were characterized by elemental analysis, IR, UV-Vis and ${ }^{1} \mathrm{H} \&{ }^{13} \mathrm{C} \mathrm{NMR}$. All complexes show $\mathrm{V}=\mathrm{O}$ stretching vibrations between 932 and $1050 \mathrm{~cm}^{-1}$. The presence of three $\mathrm{d}-\mathrm{d}$ transitions occurring between 400 and $625 \mathrm{~nm}$ confirm the $\mathrm{d}^{1}$ electronic configuration of the complexes. Based on spectral and magnetic studies, an octahedral geometry is assigned for all the complexes. The electrochemical behavior of some complexes was also investigated using cyclic voltammetry. The complexes exhibit positive antibacterial activities but showed negative antifungal activity. The free-radical-scavenging ability of the metal complexes was also determined by their interaction with the stable free radical 2,2-diphenyl-1-picrylhydrazyl, which showed encouraging antioxidant activities.
\end{abstract}

Keywords: Oxovanadium, Benzimidazole, Antioxidant activities

\section{Introduction}

The great interest in synthetic macrocycles and their corresponding metal complexes is related to the fact that they can mimic naturally-occurring macrocyclic molecules in their structural features. The formation of macrocyclic complexes depends significantly on the dimension of the internal cavity, on the rigidity of the macrocycle, on the nature of its donor atoms and on the complexing properties of the counter ion $^{1-3}$. Porphyrins are an important class of macrocyclic ligands in coordination chemistry and find extensive applications in different fields. These ligands and their biologically active complexes often find extensive applications in the coordination chemistry of transition metals, radiopharmaceuticals for cancer targeting ${ }^{4}$, agrochemicals ${ }^{5}$, model systems for biological macro molecules ${ }^{6}$, catalysts ${ }^{7}$ and as dioxygen carriers ${ }^{8}$. With their versatile structures, redox behaviour and physicochemical properties, transition metal complexes are often useful as chemical nucleases ${ }^{9}$. Metal based drugs represent a novel group of antimicrobial agents with potential applications for the control of bacterial and fungal infections. Also benzimidazoles belonging to the fused 
heterocyclic system are associated with diverse pharmaceutical activities such as antibacterial, insecticidal, fungicidal, antimicrobial, antagonist, anthelmintic and antiinflamonatary etc., ${ }^{10}$.

Also, metal based antioxidants have received recent attention for their capacity to protect organisms and cells from damage induced by oxidative stress ${ }^{11,12}$. An effective antioxidant, however, should be able to terminate the attack of reactive species like free radicals and prevent them from attacking body cells. The antioxidant activity of a synthetic compound can be measured using the scavenging ability of that compound to trap free radicals ${ }^{13}$.

All this inspires synthetic chemists to search for new metal complexes for bioactive compounds. A literature search revealed that a large number of porphyrin transition metal benzimidazole complexes have been prepared and characterized but no work has been done on oxovanadium(IV)porphyrin benzimidazole complexes. Also in view of the potential biological activity and practical applications of the porphyrin complexes, we have reported the synthesis, characterization, antibacterial and antioxidant studies of a few oxovanadium(IV) porphyrin complexes with 2-methyl and 2-ethyl substituted benzimidazoles as axial ligands.

\section{Experimental}

All the chemicals were of analytical grade and used as received unless otherwise noted. Pyrrole was distilled over potassium hydroxide pellets under vacuum prior to use. All the organic solvents that were used for the synthesis and for chromatographic separations were dried before use. (TBA) $\mathrm{PF}_{6}$ was recrystallized twice from EtOAc and dried in vacuo prior to use. Elementary analysis (C, H, N and S) were obtained on a Vario EL III and CHNS-932 Leco Elemental Analyzer. UV-vis spectra were recorded on a T90+ UV/VIS spectrophotometer in the range 350$700 \mathrm{~nm}$. Infrared spectra were recorded on a Perkin Elmer-spectrum 400 FTIR spectrophotometer using $\mathrm{KBr}$ pellets in the range of $4000-400 \mathrm{~cm}^{-1}$. The ${ }^{1} \mathrm{H}$ NMR spectra were recorded on a BrukerAvance II 500 (500 MHz) using tetramethylsilane as internal standard and $\mathrm{CDCl}_{3}$ as solvent. The Cyclic Voltammetry measurements were carried out by an Autolab Computer-controlled electrochemical measurement system equipped with a potentiostat. A three electrode system comprised a gold working electrode, a Pt wire counter electrode, and a saturated $\mathrm{Ag} / \mathrm{AgCl}$ in $\mathrm{KCl}$ as reference electrode. A $0.1 \mathrm{M}$ solution of $n$-tetrabutylammoniumhexafluorophosphate, (TBA) $\mathrm{PF}_{6}$ in freshly distilled $\mathrm{CH}_{2} \mathrm{Cl}_{2}$ was used as a supporting electrolyte during the electrochemical experiments. The scan rate was $20 \mathrm{~m} \mathrm{~V} / \mathrm{s}$ and the range was -0.2-0.2 $\mathrm{mV}$. The concentration of the porphyrins was $10^{-6} \mathrm{M}$. The solutions were purged with oxygen free nitrogen gas prior to measurements and all measurements were made at room temperature.

\section{Biological studies}

\section{Antibacterial studies}

Qualitative analysis for screening of antibacterial activity was carried out by Agar-well diffusion method ${ }^{14}$ with modifications. The samples were tested for antibacterial activity against six bacterial strains i.e. Micrococcus luteus, Enterococcus fecalis, Bacillus cereus, Bacillus subtilis, Alcaligenes denitrificans and Pseudomonas alcaligenes. $20 \mathrm{~mL}$ of sterilized nutrient agar was inoculated with $100 \mathrm{~mL}$ of bacterial suspension $(108 \mathrm{CFU} / \mathrm{mL})$ and then, poured on to sterilized petri plate. The agar plate was left to solidify at room temperature. A well of $6 \mathrm{~mm}$ was aseptically bored into the agar plate. Then, $20 \mathrm{~mL}$ of the complexes (diluted with DMSO, 1:1) was added in each well. Chloremphenicol $(10 \mu \mathrm{g})$ was used as a positive reference to determine the sensitivity of bacteria. The plates were kept at $4{ }^{\circ} \mathrm{C}$ for $2 \mathrm{~h}$ to allow the dispersal and then incubated at $37^{\circ} \mathrm{C}$ for $24 \mathrm{~h}$. 


\section{1,1-Diphenyl-2-picrylhydrazyl (DPPH) radical scavenging assay}

In this assay, free radical scavenging activity was determined (Table 1) by measuring the bleaching of purple-colored methanol solution of DPPH radical. The radical scavenging activity was determined according to the method of Blois et al.with modifications ${ }^{15}$. A total of $1 \mathrm{~mL}$ from a $0.5 \mathrm{mM}$ methanol solution of the DPPH radical was mixed to $2 \mathrm{~mL}$ sample and to this $2 \mathrm{~mL}$ of $0.1 \mathrm{M}$ sodium acetate buffer ( $\mathrm{pH}$ 5.5) was added. The mixtures were well shaken and kept at room temperature in the dark for $30 \mathrm{~min}$. The absorbance was measured at $517 \mathrm{~nm}$ using a double beam UV-Vis spectrophotometer. The radical scavenging activity (RSA) was calculated as a percentage of DPPH radical discoloration, using the equation: $\% \mathrm{RSA}=\left[\left(\mathrm{A}_{0}-\mathrm{A}_{\mathrm{s}}\right) / \mathrm{A}_{0}\right] \times 100$ where, $A_{0}$ is the absorbance of the control and $A_{s}$ is the absorbance of the test compound.

Table 1. 1,1-Diphenyl-2-picrylhydrazyl (DPPH) radical scavenging assay

\begin{tabular}{ccc}
\hline S. No. & Samples & DPPH radical scavenging activity $\left(\mathrm{IC}_{50} \mu \mathrm{g} / \mathrm{mL}\right)$ \\
\hline 1. & V-1 & 37 \\
2. & V-2 & 36.5 \\
3. & V-3 & 48 \\
4. & V-4 & 75 \\
5. & V-5 & - \\
6. & V-6 & - \\
7. & V-7 & 53 \\
8. & V-8 & 45 \\
\hline
\end{tabular}

\section{Synthesis of axially ligated oxovanadium(IV) porphyrins complexes}

\section{Synthesis of macrocycles and axial ligands}

$\mathrm{RTPPH}_{2}$ and VORTPP were synthesized according to literature methods ${ }^{16,17}$. 2-Methyl and 2-ethyl benzimidazoles (2-Mebmz \& 2-Etbmz) have also been prepared according to the procedure documented in the literature ${ }^{18}$.

Synthesis of axially ligated VO(IV) porphyrins: 2-MeVO(RTPP) and 2-EtVO(RTPP) Benzimidazoles $\left(3.211 \times 10^{-2} \mathrm{mmol}\right)$ (as axial ligand) and [VO(RTPP)] in 1:1 molar ratio were stirred. After completion of reaction as again indicated by TLC, the reaction mixture is extracted with distilled water. The extracted portion containing compound was evaporated by vacuum pump and the dried product was then dissolved in chloroform and filtered through anhydrous sodium sulphate and evaporated by vacuum pump. Finally, the purification of the product was done by column chromatography through basic alumina using chloroform as the eluent. The dried product was crystallized with chloroform and recrystallized with petroleum ether. Yield was found to be $30-35 \%$.

The compounds synthesised are listed below

V-1:5,10,15,20-tetraphenylporphyrinyloxovanadium(IV)2-methylbenzimidazole

V-2:5,10,15,20-tetraphenylporphyrinyloxovanadium(IV)2-ethylbenzimidazole

V-3:5,10,15,20-tetrakis (4-methylphenyl)porphyrinyloxovanadium(IV)2-methylbenzimidazole

V-4:5,10,15,20-tetrakis(4-methylphenylporphyrinyloxovanadium(IV)2-methylbenzimidazole

V-5:5,10,15,20-tetrakis(4-methoxyphenyl)porphyrinyloxovanadium(IV)2-methylbenzimidazole V-6:5,10,15,20-tetrakis(4-methoxyphenyl)porphyrinyloxovanadium(IV)2-methylbenzimidazole V-7:5,10,15,20-tetrakis(4-chlorophenyl)porphyrinyloxovanadium(IV)2-methylbenzimidazole V-8:5,10,15,20-tetrakis(4-chlorophenyl)porphyrinyloxovanadium(IV)2-methylbenzimidazole 


\section{$[(2-M e b m z) V O(T P P)](\boldsymbol{V}-\mathbf{1})$}

$\mathrm{UV}$-vis $\left(\mathrm{CHCl}_{3}\right): \lambda_{\max }$ (in $\left.\mathrm{nm}\right)(\log \varepsilon) 427.0(4.700)$ for $B$-band and 560.2(4.272) and 608.0(4.102) for Q- bands; IR $\left(\mathrm{KBr}, \mathrm{cm}^{-}\right): 1001(\mathrm{~V}=\mathrm{O}) ;{ }^{1} \mathrm{H}$ NMR $\left(\mathrm{CDCl}_{3}\right): \delta 9.0(\mathrm{~s}, 8 \mathrm{H}$, $\beta$-Pyrrole Protons), $8.18\left(\mathrm{~d}, 10 \mathrm{H}, J=7, \mathrm{H}_{\mathrm{o}}\right), 7.99\left(\mathrm{~m}, 14 \mathrm{H}, \mathrm{H}_{\mathrm{m} . \mathrm{p}}\right)$ for meso-aryl Protons and $2.00\left(\mathrm{~s}, 3 \mathrm{H}, \mathrm{CH}_{3}\right), 6.11-6.14(2 \mathrm{H}, \mathrm{m}, \mathrm{ArH})$ and $7.00-7.23(2 \mathrm{H}, \mathrm{m}, \mathrm{ArH})$ for bmz protons; ${ }^{13} \mathrm{C}$ NMR $\left(\mathrm{CDCl}_{3}\right)$ : 123.5, 128.4, 128.8, 131.5, 135.0, 142.6145.0, 15.2, 24.6, 115.4, 121.6, 139.2 and 151.7 ppm. Anal. Calcd for $\mathrm{C}_{52} \mathrm{H}_{36} \mathrm{~N}_{6} \mathrm{VO}$ (811.82): C, 76.93; H, 4.47; N, 10.35; found: $\mathrm{C}, 76.02 ; \mathrm{H}, 4.40 ; \mathrm{N}, 10.82 \%$.

\section{$[(2-E t b m z) V O(T P P)](\boldsymbol{V}-2)$}

$\mathrm{UV}$-vis $\left(\mathrm{CHCl}_{3}\right): \lambda_{\max }$ (in $\left.\mathrm{nm}\right)(\log \varepsilon)$ 427.6(4.742) for $B$-band and 559.7(4.284) and 609.8(4.109) for Q- bands; IR $\left(\mathrm{KBr}, \mathrm{cm}^{-}\right): 995(\mathrm{~V}=\mathrm{O}) ;{ }^{1} \mathrm{H}$ NMR $\left(\mathrm{CDCl}_{3}\right): \delta 9.3(\mathrm{~s}, 8 \mathrm{H}$, $\beta$-Pyrrole Protons), $8.18\left(\mathrm{~d}, 10 \mathrm{H}, J=7, \mathrm{H}_{\mathrm{o}}\right) \& 7.95\left(\mathrm{~m}, 14 \mathrm{H}, \mathrm{H}_{\mathrm{m} . \mathrm{p}}\right)$ for meso-aryl Protons and $2.01\left(\mathrm{~s}, 3 \mathrm{H}, \mathrm{CH}_{3}\right), 6.13-6.16(\mathrm{~m}, 2 \mathrm{H}, \mathrm{ArH})$ and 7.21-7.23(m, $\left.2 \mathrm{H}, \mathrm{ArH}\right)$ for bmz protons; ${ }^{13} \mathrm{C}$ NMR $\left(\mathrm{CDCl}_{3}\right): 123.9,128.5,128.9,131.5,134.9,142.6$ 145.0, 14.8, 23.9, 114.6, 121.2, 138.9 and 151.1 ppm.; Anal. Calcd for $\mathrm{C}_{53} \mathrm{H}_{38} \mathrm{~N}_{6} \mathrm{VO}$ (825.85): C, 77.08; H, 4.64; N, 10.18; found: $\mathrm{C}, 76.99 ; \mathrm{H}, 4.61 ; \mathrm{N}, 10.12 \%$.

\section{[(2-Mebmz)VO(p-CH3 TPP)] (V-3)}

$\mathrm{UV}$-vis $\left(\mathrm{CHCl}_{3}\right): \lambda_{\max }$ (in $\left.\mathrm{nm}\right)(\log \varepsilon) 428.2(4.740)$ for $B$-band and 558.3(4.184) and 609.3(4.102) for Q- bands; IR $\left(\mathrm{KBr}, \mathrm{cm}^{-}\right): 1015(\mathrm{~V}=\mathrm{O}) ;{ }^{1} \mathrm{H}$ NMR $\left(\mathrm{CDCl}_{3}\right): \delta 9.3(\mathrm{~s}, 8 \mathrm{H}$, $\beta$-Pyrrole Protons), $8.18\left(\mathrm{~d}, 10 \mathrm{H}, J=7, \mathrm{H}_{\mathrm{o}}\right) \& 7.95\left(\mathrm{~m}, 14 \mathrm{H}, \mathrm{H}_{\mathrm{m} . \mathrm{p}}\right)$ for meso-aryl Protons and $2.02\left(\mathrm{~s}, 3 \mathrm{H}, \mathrm{CH}_{3}\right), 6.12-6.14(\mathrm{~m}, 2 \mathrm{H}, \mathrm{ArH})$ and 7.11-7.21(m, $\left.2 \mathrm{H}, \mathrm{ArH}\right)$ for bmz protons; ${ }^{13} \mathrm{C}$ NMR $\left(\mathrm{CDCl}_{3}\right): 123.1,128.7,128.8,131.5,135.0,141.6$ 145.2, 14.9, 24.3, 112.5, 122.6, 139.9 and 150.9 ppm.; Anal. Calcd for $\mathrm{C}_{56} \mathrm{H}_{46} \mathrm{~N}_{6} \mathrm{VO}$ (869.32): C, 77.32; H, 5.33; N, 9.66; found: C, 77.30; H, 5.28; N, 9.82\%.

\section{[(2-Etbmz) $\left.\mathrm{VO}\left(\mathrm{p}-\mathrm{CH}_{3} \mathrm{TPP}\right)\right](\mathrm{V}-\mathbf{4})$}

UV-vis $\left(\mathrm{CHCl}_{3}\right): \lambda_{\max }$ (in $\left.\mathrm{nm}\right)(\log \varepsilon)$ 426.4(4.755) for $B$-band and 560.1(4.274) and 609.1(4.110) for Q- bands; IR $\left(\mathrm{KBr}, \mathrm{cm}^{-}\right): 988(\mathrm{~V}=\mathrm{O})$; ${ }^{1} \mathrm{H}$ NMR $\left(\mathrm{CDCl}_{3}\right): \delta 9.3(\mathrm{~s}, 8 \mathrm{H}$, $\beta$-Pyrrole Protons), $8.18\left(\mathrm{~d}, 10 \mathrm{H}, J=7, \mathrm{H}_{\mathrm{o}}\right) \& 7.95\left(\mathrm{~m}, 14 \mathrm{H}, \mathrm{H}_{\mathrm{m} . \mathrm{p}}\right)$ for meso-aryl Protons and $2.03\left(\mathrm{~s}, 3 \mathrm{H}, \mathrm{CH}_{3}\right), 6.13-6.14(2 \mathrm{H}, \mathrm{m}, \mathrm{ArH})$ and 7.21-7.23(2H, m, ArH) for bmz protons; ${ }^{13} \mathrm{C}$ NMR $\left(\mathrm{CDCl}_{3}\right)$ : 123.5, 128.3, 128.8, 131.4, 135.0, 142.2 145.0, 15.3, 24.5, 114.6, 121.2, 139.1 and 151.5 ppm.; Anal. Calcd for $\mathrm{C}_{57} \mathrm{H}_{48} \mathrm{~N}_{6} \mathrm{VO}$ (883.33): C, 77.45; H, 5.47; N, 9.51; found: C, $77.42 ; \mathrm{H}, 5.40 ; \mathrm{N}, 9.42 \%$.

\section{$\left[(2-\mathrm{Mebmz}) \mathrm{VO}\left(\mathrm{p}-\mathrm{OCH} \mathrm{HPP}_{3}\right)\right](\mathrm{V}-5)$}

$\mathrm{UV}$-vis $\left(\mathrm{CHCl}_{3}\right): \lambda_{\max }$ (in $\left.\mathrm{nm}\right)(\log \varepsilon)$ 427.1(4.712) for $B$-band and 558.7(4.248) and 608.1(4.106) for Q- bands; IR $\left(\mathrm{KBr}, \mathrm{cm}^{-}\right): 970(\mathrm{~V}=\mathrm{O}) ;{ }^{1} \mathrm{H}$ NMR $\left(\mathrm{CDCl}_{3}\right): \delta 9.3(\mathrm{~s}, 8 \mathrm{H}$, $\beta$-Pyrrole Protons) and $2.04\left(\mathrm{~s}, 3 \mathrm{H}, \mathrm{CH}_{3}\right), 6.11-6.13(2 \mathrm{H}, \mathrm{m}, \mathrm{ArH})$ and 7.09-7.23(2H, $\mathrm{m}$, ArH) for bmz protons, $8.18\left(\mathrm{~d}, 10 \mathrm{H}, J=7, \mathrm{H}_{\mathrm{o}}\right) \& 7.95\left(\mathrm{~m}, 14 \mathrm{H}, \mathrm{H}_{\mathrm{m} . \mathrm{p}}\right)$ for meso-aryl Protons; ${ }^{13} \mathrm{C}$ NMR $\left(\mathrm{CDCl}_{3}\right)$ : 123.5, 128.3, 128.8, 131.5, 135.0, 141.5 145.0, 15.1, 24.6, 112.9, 121.3, 139.4 and 150.1 ppm.; Anal. Calcd for $\mathrm{C}_{56} \mathrm{H}_{46} \mathrm{~N}_{6} \mathrm{O}_{5} \mathrm{~V}$ (933.3): C, 72.02; H, 4.96; N, 9.00; found: $\mathrm{C}, 72.00 ; \mathrm{H}, 4.90 ; \mathrm{N}, 8.82 \%$.

\section{[(2-Etbmz) VO(p-OCH $\left.\left.\mathrm{CHP}_{3}\right)\right](\mathbf{V}-\mathbf{6})$}

UV-vis $\left(\mathrm{CHCl}_{3}\right): \lambda_{\max }$ (in $\left.\mathrm{nm}\right)(\log \varepsilon)$ 427.1(4.551) for $B$-band and 558.9(4.223) and 607.2(4.100) for Q- bands; IR $\left(\mathrm{KBr}, \mathrm{cm}^{-}\right): 1003(\mathrm{~V}=\mathrm{O}) ;{ }^{1} \mathrm{H} \mathrm{NMR}\left(\mathrm{CDCl}_{3}\right): \delta 9.3(\mathrm{~s}, 8 \mathrm{H}$, 
$\beta$-Pyrrole Protons) and $2.02\left(\mathrm{~s}, 3 \mathrm{H}, \mathrm{CH}_{3}\right), 6.10-6.13(2 \mathrm{H}, \mathrm{m}, \mathrm{ArH})$ and 7.02-7.24(2H, m, ArH) for bmz protons, $8.18\left(\mathrm{~d}, 10 \mathrm{H}, J=7, \mathrm{H}_{\mathrm{o}}\right) \& 7.95\left(\mathrm{~m}, 14 \mathrm{H}, \mathrm{H}_{\mathrm{m} . \mathrm{p}}\right)$ for meso-aryl Protons; ${ }^{13} \mathrm{C} \mathrm{NMR}\left(\mathrm{CDCl}_{3}\right): 121.2,128.4,128.8,132.5,135.0,142.0$ 145.0, 15.2, 24.6, 114.5, 121.3, 138.2 and 151.6 ppm.; Anal. Calcd for $\mathrm{C}_{57} \mathrm{H}_{58} \mathrm{~N}_{6} \mathrm{O}_{5} \mathrm{~V}$ (958.05): C, 71.46; H, 6.10; N, 8.77; found: C, 71.42; H, 6.01; N, 8.72\%.

[(2-Mebmz)VO(p-ClTPP)] $(\mathrm{V}-7)$

$\mathrm{UV}$-vis $\left(\mathrm{CHCl}_{3}\right): \lambda_{\max }$ (in $\left.\mathrm{nm}\right)(\log \varepsilon)$ 426.9(4.700) for $B$-band and 560.7(4.112) and 609.8(4.108) for Q- bands; IR $\left(\mathrm{KBr}, \mathrm{cm}^{-}\right): 1002(\mathrm{~V}=\mathrm{O}) ;{ }^{1} \mathrm{H}$ NMR $\left(\mathrm{CDCl}_{3}\right): \delta 9.3(\mathrm{~s}, 8 \mathrm{H}$, $\beta$-Pyrrole Protons), $8.18\left(\mathrm{~d}, 10 \mathrm{H}, J=7, \mathrm{H}_{\mathrm{o}}\right) \& 7.95\left(\mathrm{~m}, 14 \mathrm{H}, \mathrm{H}_{\mathrm{m} . \mathrm{p}}\right)$ for meso-aryl Protons and $2.02\left(\mathrm{~s}, 3 \mathrm{H}, \mathrm{CH}_{3}\right), 6.12-6.15(2 \mathrm{H}, \mathrm{m}, \mathrm{ArH})$ and 7.06-7.22(2H, m, ArH) for bmz protons $;{ }^{13} \mathrm{C}$ NMR $\left(\mathrm{CDCl}_{3}\right)$ : 123.5, 128.4, 128.8, 131.5, 135.1, 141.6 145.5, 15.6, 24.6, 114.1, 120.3, 137.4 and 153.6 ppm.; Anal. Calcd for $\mathrm{C}_{52} \mathrm{H}_{32} \mathrm{~N}_{6} \mathrm{Cl}_{4} \mathrm{VO}$ (949.6): C, 65.77; H, 3.40; N, 8.85; found: $\mathrm{C}, 65.70 ; \mathrm{H}, 3.34 ; \mathrm{N}, 8.82 \%$.

[(2-Etbmz)VO (p-ClTPP)] (V-8)

UV-vis $\left(\mathrm{CHCl}_{3}\right): \lambda_{\max }$ (in nm) (log $\left.\varepsilon\right) 427.5(4.552)$ for $B$-band and 558.6(4.184) and 610.2(4.009) for Q- bands; IR $\left(\mathrm{KBr}, \mathrm{cm}^{-}\right): 1008(\mathrm{~V}=\mathrm{O}) ;{ }^{1} \mathrm{H} \mathrm{NMR}\left(\mathrm{CDCl}_{3}\right): \delta 9.3(\mathrm{~s}, 8 \mathrm{H}, \beta$ - Pyrrole Protons), $8.18\left(\mathrm{~d}, 10 \mathrm{H}, J=7, \mathrm{H}_{\mathrm{o}}\right) \& 7.95\left(\mathrm{~m}, 14 \mathrm{H}, \mathrm{H}_{\mathrm{m} . \mathrm{p}}\right)$ for meso-aryl Protons and $2.01\left(\mathrm{~s}, 3 \mathrm{H}, \mathrm{CH}_{3}\right), 6.13-$ 6.16(2H, m, $\mathrm{ArH})$ and 7.07-7.26(2H, $\mathrm{m}, \mathrm{ArH})$ for bmz protons; ${ }^{13} \mathrm{C} \mathrm{NMR}\left(\mathrm{CDCl}_{3}\right)$ : 123.5, 127.4, 128.4, 131.4, 132.1, 146.1, 143.2, 14.9, 21.6, 113.2, 122.3, 137.1 and 152.4 ppm; Anal. Calcd for $\mathrm{C}_{53} \mathrm{H}_{34} \mathrm{~N}_{6} \mathrm{Cl}_{4} \mathrm{VO}$ (963.63): C, 66.06; H, 3.56; N, 8.72;; found: $\mathrm{C}, 66.02 ; \mathrm{H}, 3.40 ; \mathrm{N}, 8.22 \%$.

\section{Results and Discussion}

The general synthetic routes to corresponding metallated and axially ligated oxovanadium(IV) peripherally tetra-substituted tetraphenylporphyrins are shown in Scheme 1 respectively. All of these new oxovanadium(IV) porphyrin were purified by column chromatography with aluminum oxide as adsorbent and were characterized by spectral data (UV-Visible spectroscopy, IR spectroscopy, ${ }^{1} \mathrm{H} \&{ }^{13} \mathrm{C}$ NMR spectroscopy, mass spectral data and elemental analysis). The characterization data of the new compounds are consistent withthe assigned formula. All the complexes are colored and stable at room temperature. The complexes are soluble in chloroform, methanol, dimethyl sulphoxide, dimethyl formamide and acetonitrile but they are insoluble in water and acetone.

\section{Synthesis and characterization}

The structures of all substituted tetraphenylporphyrinoxovanadium(IV) benzimidazoles (2-Me/EtbmzVO(IV)RTPP) are characterized by various spectroscopic studies and the spectral data are given in experimental section.

\section{Conductance and magnetic measurements}

The molar conductance values of complexes in DMSOat $10^{-3} \mathrm{M}$ concentration are recordedthat have shown low values in the range of 7-9 $\Omega^{-1} \mathrm{~cm}^{2} \mathrm{~mol}^{-1}$ revealing their non-electrolytic nature $^{19}$ and they exhibit magnetic moments in the range 1.73-1.79 B.M. at room temperature which are in the range reported for oxovanadium(IV) complexes with one unpaired electron and hence $3 \mathrm{~d}^{1}$ configuration and also the monomeric nature of these complexes ${ }^{20}$.

\section{Electronic spectra}

The UV-Vis data shows that many of the absorption bands of the para-substituted derivatives exhibit small shifts to longer wavelength i.e. bathochromic shift (red shift) as compared to the spectrum of $\mathrm{H}_{2}$ RTPP. The most pronounced bathochromic shift occurs in $p$-CITPP with para- 
chloro group on meso-phenyl ring of the porphyrin but in all the substituted tetraphenylporphyrin, intensities of all the peaks are higher than those of the parent tetraphenylporphyrin. The reason might be that the- $\mathrm{Cl}$ group decreased the electronic density of the porphyrin ring when compared with other groups substituted on tetraphenylporphyrins due to its electron withdrawing nature. Thus, the $\pi-\pi^{*}$ electron excitation of the porphyrin ring required absorbing the light of smaller energy (longer wavelength).
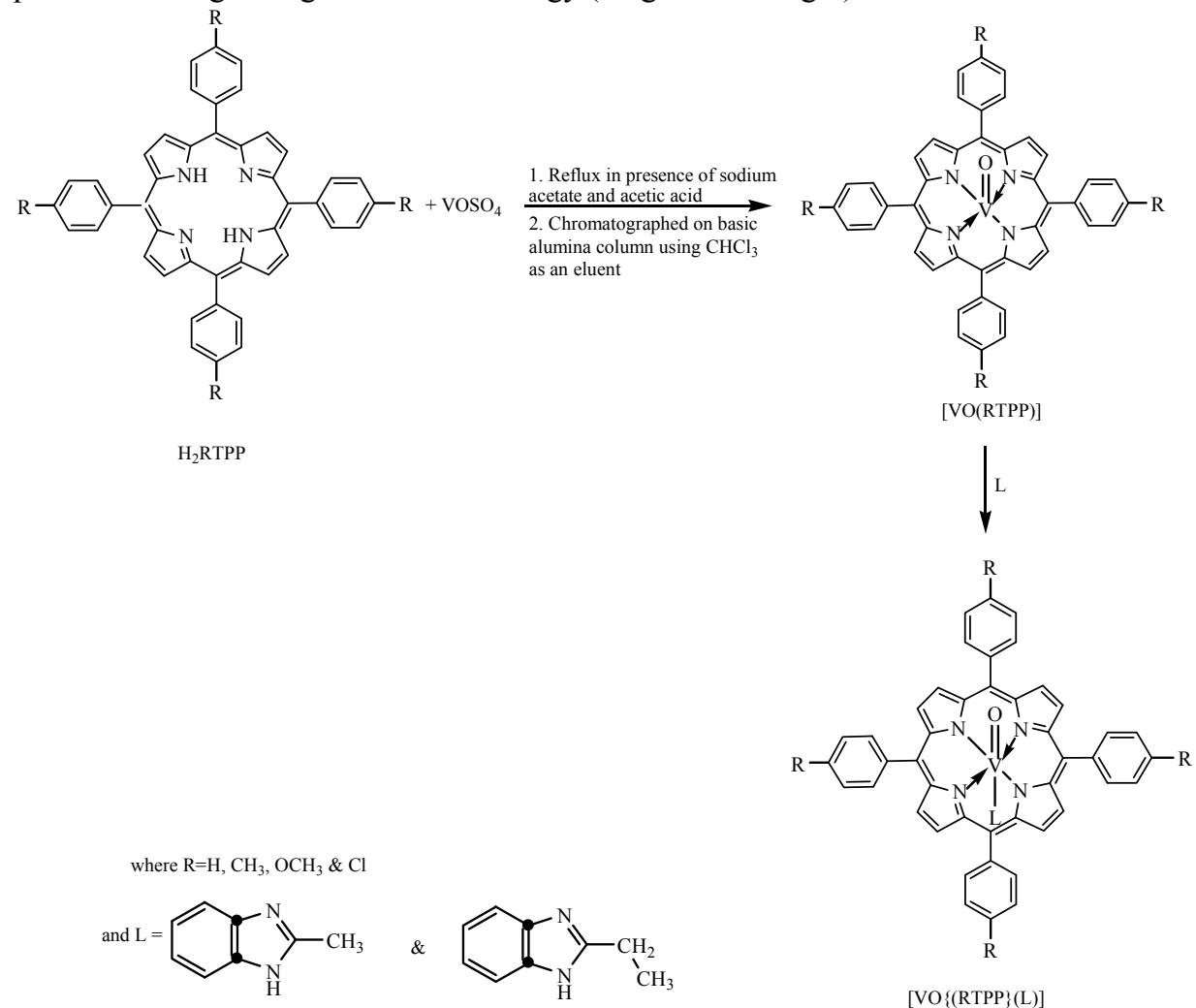

Scheme 1. Synthesis of metallated and axially ligated oxovanadium(IV) peripherally tetrasubstituted tetraphenylporphyrins

By comparing the UV-Vis data of complexes, it was noticed that in the visible absorption spectra, free base porphyrins show an intense Soret band at around $400 \mathrm{~nm}$ and four weaker Q bands between $450 \mathrm{~nm}$ and $650 \mathrm{~nm}$. When the metal ion was inserted into the porphyrin ring the number and intensity of the $\mathrm{Q}$ bands was found to decrease and the $\mathrm{B}$ (Soret) band showed a slight blue shift. The reason might be that the structural symmetry of oxovanadium(IV) porphyrin compounds was improved and the energy gap decreased as compared to the free base porphyrins ${ }^{21}$. In axially ligated oxovanadium(IV) porphyrin complexes both B and Q band regions of the spectra show slight red shift which may be due to the basic nature of thebenzimidazolesas these can easily donate non-bonding electrons present on heteroatom nitrogen and hence requires less energy for transition and therefore shows bathochromic shifts. There is also a formation of new band around $610 \mathrm{~nm}$ in axially ligated complexs showing their octahedral geometry around the metal $\operatorname{ion}^{22}$. The comparison of UV-Visible data of some complexes is shown in Figure 1. 


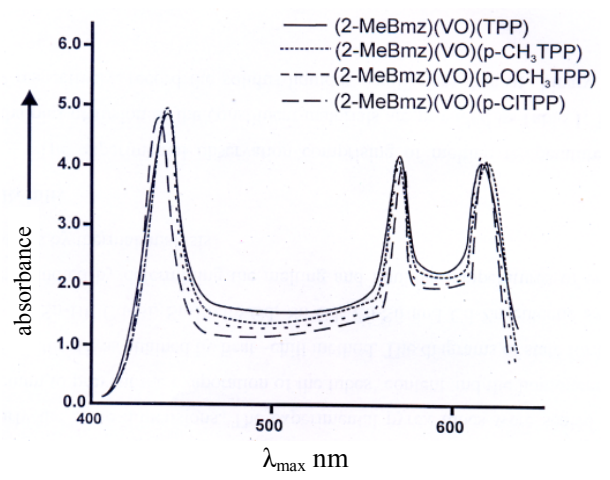

Figure 1. UV- visible spectra

\section{IR spectra}

Infrared spectral data of above porphyrin compounds is also given in experimental section. It is found that the $v(\mathrm{~N}-\mathrm{H})$ stretching and bending frequencies of free base porphyrins are located at $\sim 3400-3320 \mathrm{~cm}^{-1}$ and $\sim 960 \mathrm{~cm}^{-1}$ respectively ${ }^{23}$. When the oxovanadium ion was inserted into the porphyrin ring, the $\mathrm{N}-\mathrm{H}$ vibration frequency of free base porphyrins disappeared and the characteristic $v(\mathrm{~V}=\mathrm{O})$ vibration frequency found at $\sim 950-1050 \mathrm{~cm}^{-1}$, which indicated the formation of oxovanadium(IV) porphyrin compounds ${ }^{24}$. In the spectra of all the axially ligated oxovanadium(IV) porphyrin complexes the band due to $v(\mathrm{~V}=\mathrm{O})$ vibration frequency gets shifted to lower values in comparison to metallatedporphyrins ${ }^{25}$. The band assigned to the $v(\mathrm{C}-\mathrm{O})$ stretching show upward shift in the range $\sim 1264-1249 \mathrm{~cm}^{-1}$, which is due to the coordination of the bmz nitrogen to $\mathrm{VO}(\mathrm{IV})$ porphyrins. The incorporation of 2-Me/Etbmz in $\mathrm{VO}$ (IV) metal derivatives of different porphyrins i.e., 2-Me/EtbmzVORTPP, is further confirmed by the appearance of $\mathrm{V}-\mathrm{N}$ vibrational frequencies in the range $450-550 \mathrm{~cm}^{-1}$ corresponding to the ligation of oxovanadium to nitrogen of $2-\mathrm{Me} / \mathrm{Etbmz}^{22}$. This band of porphyrin ring being weak and indistinguishable usually $^{24}$. Thus, the vanadium atom in the centre of porphyrin ring coordinate with the bmzgroup axially to form six-coordinate complex of $\mathrm{VO}(\mathrm{IV})$ porphyrin.

\section{${ }^{1} H N M R$}

On comparing the ${ }^{1} \mathrm{H}$ NMR data of free base porphyrin, their corresponding metallated and axially ligated oxovanadium(IV) porphyrin complexes, it was found that in all themetallatedporphyrins there was absence of signal related to $\mathrm{N}-\mathrm{H}$ protons and shift in other signals indicating the insertion of oxovanadium in porphyrin macrocycle ${ }^{26}$. Generally, the presence of VO(IV) metal in the porphyrin ring shifts the resonances of the porphyrin's protons to down-field. In axially ligated oxovanadium(IV) porphyrin complexes, the signals of axial 2-methyl and ethyl benzimidazole fragment protons are shifted to higher field in comparison to the signals of porphyrin protons and also in comparison to proton signals of free 2methylbenzimidazole and 2-ethyl benzimidazole acid respectively ${ }^{22}$. These positions of protons show that axial ligand is under the influence of $\pi$-conjugated system of porphyrin macrocycle.

\section{Mass studies}

The mass spectra of these complexes show molecular ion peaks which are in good agreement with the structure suggested by elemental analysis and spectral and magnetic studies. For example, for molecular ions [(2-Mebmz)VO(TPP) $]^{+},[(2-E t b m z) V O(T P P)]^{+}$, $\left[(2-\mathrm{Mebmz}) \mathrm{VO}\left(p-\mathrm{CH}_{3} \mathrm{TPP}\right)\right]^{+},\left[(2-\mathrm{Etbmz}) \mathrm{VO}\left(p-\mathrm{CH}_{3} \mathrm{TPP}\right)\right]^{+},[(2-\mathrm{Mebmz}) \mathrm{VO}(p-\mathrm{OMeTPP})]^{+}$, 
[(2-Etbmz)VO $(p$-OMeTPP $)]^{+},[(2-\mathrm{Mebmz}) \mathrm{VO}(p-\mathrm{ClTPP})]^{+},[(2-\mathrm{Etbmz}) \mathrm{VO}(p \text {-ClTPP })]^{+}$are $810.942,814.942,866.942,880.942,930.942,944.942,948.942$ and 960.942 respectively.

\section{Electrochemical studies}

Electrochemical data obtained from cyclic voltammetric studies reveal that most of the synthesizedcomplexes undergo two one-electron oxidations due to $\pi$-cation radical and dication formation and three one-electron reductions (Figure 2). The first two reductions are because of $\pi$-anion radical and dianion formation, while the third quasi-reversible reduction is assigned to a metal-centered process $\left(\mathrm{V}^{\mathrm{IV}} \neg \mathrm{V}^{\mathrm{III}}\right)$. All of the complexes reported are redox active in solution and the potentials are summarized in Table 2. From the table it has been found that substitution of the meso positions with an electron withdrawing group $(\mathrm{Cl}-)$ enhanced reduction and inhibits oxidation when compared with the electron releasing ${ }^{25}$ groups $\left(-\mathrm{CH}_{3}\right.$ and $\left.-\mathrm{OCH}_{3}\right)$.

These results can be useful for identifying the interaction of the vanadylporphyrins with the biological targets in their reported involvement in potent insulinomimetic activity and in anti-HIV agents ${ }^{27}$.

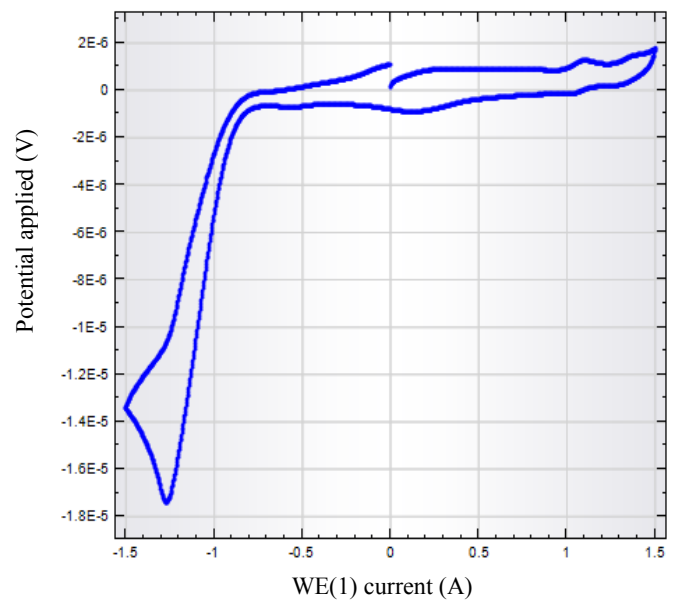

Figure 2. Cyclic voltammogram of [(2-Mebmz)VO(p-ClTPP $)]$

Table 2. Electrochemical data

\begin{tabular}{cccccc}
\hline Species & $\mathrm{E}_{\mathrm{OX} 2} / \mathrm{V}$ & $\mathrm{E}_{\mathrm{OX} 1} / \mathrm{V}$ & $\mathrm{E}_{\mathrm{red} 1} / \mathrm{V}$ & $\mathrm{E}_{\mathrm{red} 2} / \mathrm{V}$ & $\mathrm{E}_{\mathrm{red} 3} / \mathrm{V}$ \\
\hline$[(2-\mathrm{Mebmz}) \mathrm{VO}(\mathrm{TPP})]$ & 1.13 & 1.25 & -1.30 & -1.42 & -1.51 \\
{$\left[(2-\mathrm{Mebmz}) \mathrm{VO}\left(\mathrm{p}-\mathrm{CH}_{3} \mathrm{TPP}\right)\right]$} & 1.25 & 0.68 & -1.22 & -1.32 & -1.50 \\
{$\left[(2-\mathrm{Mebmz}) \mathrm{VO}\left(\mathrm{p}-\mathrm{OCH}{ }_{3} \mathrm{TPP}\right)\right]$} & 1.28 & 0.70 & -1.15 & -1.21 & -1.42 \\
{$[(2-M e b m z) \mathrm{VO}(\mathrm{p}-\mathrm{ClTPP})]$} & 1.21 & - & -1.35 & - & - \\
\hline
\end{tabular}

\section{Antibacterial Studies}

Antibacterial activity of the synthesized compounds [(2-Mebmz)VO(TPP)] (V-1), [(2-Etbmz) $\mathrm{VO}(\mathrm{TPP})] \quad(\mathbf{V}-\mathbf{2}), \quad\left[(2-\mathrm{Mebmz}) \mathrm{VO}\left(p-\mathrm{CH}_{3} \mathrm{TPP}\right)\right] \quad(\mathbf{V}-\mathbf{3}),\left[(2-\mathrm{Etbmz}) \mathrm{VO}\left(p-\mathrm{CH}_{3} \mathrm{TPP}\right)\right] \quad(\mathbf{V}-\mathbf{4})$, $\left[(2-\mathrm{Mebmz}) \mathrm{VO}\left(p-\mathrm{OCH}_{3} \mathrm{TPP}\right)\right] \quad(\mathbf{V}-5),\left[(2-\mathrm{Etbmz}) \mathrm{VO}\left(p-\mathrm{OCH}_{3} \mathrm{TPP}\right)\right] \quad(\mathbf{V}-\mathbf{6})$ and $[(2-\mathrm{Mebmz})$ $\left.\mathrm{VO}\left(p-\mathrm{CH}_{3} \mathrm{TPP}\right)\right](\mathbf{V}-7),\left[(2-\mathrm{Etbmz}) \mathrm{VO}\left(\mathrm{p}-\mathrm{CH}_{3} \mathrm{TPP}\right)\right](\mathbf{V}-\mathbf{8})$ was tested by agar-well-diffusion method (Table 3). The samples were tested for antibacterial activity against six bacterial strains i.e. Micrococcus luteus, Enterococcus fecalis, Bacillus cereus, Bacillus subtilis, Alcaligenesdenitrificansand Pseudomonas alcaligenes. $\mathbf{V - 1}$ showed good antibacterial activity against M. luteus $(13 \pm 0.13 \mathrm{~mm})$, A. denitrificans $(16 \pm 0.06 \mathrm{~mm})$ and $P$. alcaligenes $(14 \pm 0.23 \mathrm{~mm})$ 
which was comparable to the positive control (Table 3). V-2 also showed quite remarkable antibacterial effect against $M$. luteus $(12 \pm 0.23 \mathrm{~mm}), A$. denitrificans $(17 \pm 0.12 \mathrm{~mm})$ and $P$. alcaligenes $(10 \pm 0.32 \mathrm{~mm})$. V-3 showed inhibition against only M. luteus $(14 \pm 0.12 \mathrm{~mm})$. V-4 and $\mathbf{V}-5$ showed moderate activity against only one bacterial strain i.e. A. denitrificans $(13 \pm 0.14 \mathrm{~mm})$ and $(11 \pm 0.02 \mathrm{~mm})$ respectively. V-6 showed good activity against $B$. cereus $(18 \pm 0.32 \mathrm{~mm})$ and $A$. Denitrificans $(8 \pm 0.07 \mathrm{~mm})$. V-7 showed inhibitory effect against $M$. luteus and E. fecalis with zones of inhibition of $10 \pm 0.02 \mathrm{~mm}$ and $11 \pm 0.31 \mathrm{~mm}$ respectively. And $\mathbf{V - 8}$ showed moderate inhibitory effect against $M$. luteus $(9 \pm 0.01)$ and $A$. Denitrificans $(8.7 \pm 0.06)$.

Table 3. Antibacterial assay by agar well diffusion assay

\begin{tabular}{cccccccc}
\hline & \multicolumn{7}{c}{ Zone of inhibition, mm } \\
\cline { 2 - 7 } S.No. & Samples & $\begin{array}{c}M . \\
\text { luteus }\end{array}$ & $\begin{array}{c}\text { E. } \\
\text { fecalis }\end{array}$ & $\begin{array}{c}\text { B. } \\
\text { cereus }\end{array}$ & $\begin{array}{c}\text { B. } \\
\text { subtilis }\end{array}$ & $\begin{array}{c}\text { A. } \\
\text { denitrificans }\end{array}$ & P.alcaligenes \\
\hline 1. & $\mathbf{V}-1$ & $13 \pm 0.13$ & - & - & - & $16 \pm 0.06$ & $14 \pm 0.23$ \\
2. & $\mathbf{V}-2$ & $12 \pm 0.23$ & - & - & - & $17 \pm 0.12$ & $10 \pm 0.32$ \\
3. & $\mathbf{V}-3$ & $14 \pm 0.12$ & - & - & - & - & - \\
4. & $\mathbf{V}-4$ & - & - & - & - & $13 \pm 0.14$ & - \\
5. & $\mathbf{V}-5$ & - & - & - & - & $11 \pm 0.02$ & - \\
6. & $\mathbf{V}-6$ & - & - & $18 \pm 0.32$ & - & $8 \pm 0.07$ & - \\
7. & $\mathbf{V}-7$ & $10 \pm 0.02$ & $11 \pm 0.31$ & - & - & - & - \\
8. & $\mathbf{V}-8$ & $9 \pm 0.01$ & - & - & - & $8.7 \pm 0.06$ & - \\
9. & + control & $13 \pm 0.40$ & $14 \pm 0.79$ & $22 \pm 0.78$ & $18 \pm 0.42$ & $17 \pm 0.03$ & $18 \pm 0.39$ \\
\hline
\end{tabular}

Antioxidant studies

DPPH is a stable free radical that is often used for detection of the radical-scavenging activity in chemical analysis. The reduction capability of DPPH radicals was determined by the decrease in its absorbance at $517 \mathrm{~nm}$ which can be induced by antioxidants ${ }^{28}$. From table, the results of the antioxidant studies showed promising results with samples $\mathrm{V}-1, \mathrm{~V}-2, \mathrm{~V}-3$ and V-8 with $\mathrm{IC}_{50}$ values of $37 \mu \mathrm{g} / \mathrm{mL}, 36.5 \mu \mathrm{g} / \mathrm{mL}, 48 \mu \mathrm{g} / \mathrm{mL}$ and $45 \mu \mathrm{g} / \mathrm{mL}$ respectively. $\mathrm{V}-2$ showed remarkable radical scavenging activity with the lowest $\mathrm{IC}_{50}$ value.

\section{Antifungal studies}

All the complexes were also screened for antifungal activities against the fungus Sclerotiumrolfsiand they showed negative results.

\section{Conclusion}

On the basis of the above elemental analysis and spectral studies, confirmed by mass spectra showing characteristic molecular ion peak at their $\mathrm{m} / \mathrm{z}$ value for their monomeric form, octahedral structure is proposed for these complexes. Definite structure for the fascinating complexes in solid state would be possible only after x-ray crystallographic studies, which are under process. Further from biological activities, it was found that they showed prominent antibacterial and antioxidant activity when compared to the porphyrin complex. Negative results were found for the antifungal activities.

\section{References}

1. Sandhanamalar D, Vedanayaki S and Rajavel R, Chem Sci Trans., 2013, 2(2), 529-537; http://dx.doi.org/10.7598/cst2013.332

2. Fenton D E and Vigato P A, Chem Soc Rev., 1988, 17, 69-90; http://dx.doi.org/10.1039/CS9881700069 
3. Alexander V, Chem Rev., 1995, 95(2), 273-342; DOI:10.1021/cr00034a002

4. Hamor G H and Watson D L, J Pharm Sci., 1971, 60(6), 925-927;

DOI:10.1002/jps.2600600628

5. Taylor M K, Trotter K D, Reglinski J, Berlouis L E A, Kennedy A R, Spickett C M and Sowden R J, Inorganic Chimica Acta, 2008, 361(9-10), 2851-2862; DOI:10.1016/j.ica.2008.02.021

6. Rayati S, Torabi N, Ghaemi A, Mohebbi S, Wojtczak A and Kozakiewicz A, Inorg Chimica Acta, 2008, 361(5), 1239-1246; DOI:10.1016/j.ica.2007.08.004

7. Dai J, Chai Y, Yuan R, ZhongX, Liu Y and Tang D, Anal Sci., 2004, 20(12), 1661-1665.

8. MuruganandamL, Krishna Kumar K, and BalasubramanianK, Chem Sci Trans., 2013, 2(2), 379-384; DOI:10.7598/cst2013.335

9. Patel K V and Singh A, E-J Chem., 2009, 6(1), 281-288; DOI:10.1155/2009/756361

10. Fatma AbdAleem A ElHag, Reem A K ElHarbi, Fatma M Edress and Hoda I El Diwan, 1st Annual International Interdisciplinary Conference, AIIC 2013, 24-26 April, Azores, Portugal - Proceedings

11. Tetteh S, Dodoo D K, Appiah-Opong R and Tuffour I, J Inorg Chem., Volume 2014, Article ID 586131,7 pages.

12. Al-AmieryA A, KadhumA A H and Mohammed A B, Bioinorg Chem Appl., 2012, Volume 2012, Article ID 795812, 6 pages.

13. Choudhary A, Sharma R, Nagar M, Mohsin M and Meena H S, J Chil Chem Soc., 2011, 56(4), 911-917.

14. Oke F, Aslim B, Ozturk S and Altundag S, Food Chem., 2009, 112(4), 874-879; DOI:10.1016/j.foodchem.2008.06.061

15. Abe N, Murata T andHirota A, Biosci Biotechnol Biochem., 1998, 62(4), 661-666; DOI:10.1271/bbb.62.661

16. Longo A D, Longo F R, Finarelli J D, Goldmacher J, Assour J and Korsakoff L, J Org Chem., 1967, 32(2), 476; DOI:10.1021/jo01288a053

17. Erdman J G, Ramsey V G, KalendaN W, Hanson W E, J Am Chem Soc., 1956, 78(22), 5844-5847; DOI:10.1021/ja01603a037

18. Hein D W, Alheim R J and Leavitt J J, J Am Chem Soc., 1957, 79(2), 427-429; DOI:10.1021/ja01559a053

19. Swamy S J, Reddy A D and Bhaskar K, Indian J Chem., 2001, 40A, 1166.

20. Singh S, Rao D P, Yadawa A K and Yadav H S, Current Res Chem., 2011, 3(2), 106-113.

21. Fagadar-Cosma E, Vlascici D and Fagadar-Cosma G., In the 12th Symposium on Analytical and Environmental Problems, Szeged, 2005, 25.

22. Bajju G D, Sharma P, KapahiA, Bhagat M, Kundan S and Gupta D, J Inorg Chem., 2013, Volume 2013. Article ID 982965, 11 pages

23. Sun Z C, She Y B, Zhou Y, Song X F and Li K, Molecules, 2011, 16(4), 2960-2970; DOI:10.3390/molecules16042960

24. Baran E J, Jubert A H and Ferrer E G, J Raman Spectros., 1992, 23(9), 489-494.

25. Ghosh S K, Patra R and Rath S P, Inorg Chem., 2008, 47(21), 9848-9856; DOI:10.1021/ic800714w

26. Vlascici D, Bizerea-Spiridon O and Fagadar-Cosma E, In the 13th Symposium on Analytical and Environmental Problems, Szeged, 2006, 92.

27. Tidwell P, Bharara P, Rudeseal G, Rudeseal T, Rudeseal F H, Simmer C A, McMillan D, Lanier K, Dalila L Fondren, LaTasha L Folmar and Belmore K, Molecules, 2007, 12(7), 1389-1398; DOI:10.3390/12071389

28. Ahmed A, Amiery A, Abdul Amir H K and Abu Bakar Mohamad Bioinorg Chem Appl., 2012;DOI:10.1155/2012/795812 